cials said they do not support any form of testing that might result in discrimination and that HIV testing of foreigners is not an effective AIDS containment measure from a public health perspective.

FROM: Lancet March 11, 1995;345(8949):644.

\section{JCAHO Backs Away from Manda- tory Indicators, Invites Other Performance Measurement Systems}

The Joint Commission on Accreditation of Healthcare Organizations (JCAHO) decided to withdraw from an earlier position on mandatory use of its Indicator Measurement System (IMSystem). JCAHO recently issued written invitations to more than 250 organizations to solicit their involvement in a performance measurement partnership. This marks the first step in JCAHO's plan to include multiple performance measurement systems, in addition to its own IMSystem in its future accreditation process.

Plans are being made for tabulation of all the available measurement systems from which candidate systems will be identified for formal review by a special advisory panel. Those systems that meet a set of basic criteria, such as their willingness to share data, would be included with the IMSystem under an umbrella of alternate performance measurement systems acceptable for use in the JCAHO's future accreditation process.

Efforts also are underway to expand and strengthen the IMSystem through a second collaborative effort, involving periodic issuance of Requests for Indicators (RFIs) in different programmatic areas. The RFIs will invite organizations, professional associations, academic institutions, database developers, and others to share their expertise and indicator work products with the JCAHO.

This enhanced approach to performance measurement could become part of the accreditation process as early as 1997. Any organization interested in having its measurement system considered is invited to contact the JCAHO.

FROM: Joint Commission on Accreditation of Healthcare Organizations. Joint Commission issues invitation to performance measurement systems. News release March 8, 1995.

Burda D. JCAHO backs off on requiring use of its indicator system. M odem H ealthcare March 13, 1995, p 4.

\section{CDC Releases Draft Guidelines for HIV Counseling and Voluntary Testing for Pregnant Women}

In 1993, an estimated 7,000 HIV-infected women gave birth in the United States. The prevalence of HIV infection in women giving birth was 1.6 per 1,000 , or approximately 1 in 625. Assuming an HIV transmission rate from mother to infant of approximately $15 \%$ to $30 \%$, approximately 1,000 to 2,000 infected infants were born in the United States in 1993.

For HIV-infected women and their infants to benefit optimally from AZT and other medical treatment, it is important for women to know before or early in pregnancy whether they are HIV infected. CDC's draft guidelines promote early HIV counseling and voluntary testing to help women learn if they are infected. This will enable women to seek and receive the care they need for themselves and to reduce the chances of transmitting HIV to their infants.

In February 1994, the results of the National Institute of Health AIDS Clinical Trial 076 were announced, indicating that zidovudine (ZDV or AZT) could reduce perinatal HIV transmission by as much as two thirds in some infected women and their infants. The results were reported in the $\mathrm{N}$ ew England Journal of M edicine in November 1994. In August, the Food and Drug Administration approved AZT use for pregnant women, and the US Public Health Service issued guidelines on $\mathrm{AZT}$ use during pregnancy (M M WR 1994;43[RR-11]). There were no serious short-term side effects observed in the study, but several questions remain unanswered. The trial included a select group of women in the early stages of disease who previously had not taken AZT long-term and who had access to prenatal care. The therapy may differ in effectiveness in women who differ from these characteristics. In addition, it is not known how AZT specifically prevents transmission, the effect of any variations in therapy (eg, using AZT only during labor or in late pregnancy), or the long-term effects of AZT on mothers and infants.

The combined strategy of HIV counseling for all pregnant women and voluntary HIV testing already is proving effective in several communities. For example, in one inner-city hospital in Atlanta, 96\% of pregnant women chose to be tested after being provided HIV counseling and offered voluntary HIV testing as part of prenatal care.

Although AZT therapy is not $100 \%$ effective and the long-term risks to the mother and infant are not yet known, the Centers for Disease Control and Prevention (CDC) believes that the dramatic reduction in HIV transmission in the trial dictate that every HIV-infected pregnant woman should be offered AZT therapy to reduce the risk of HIV transmission to the infant.

Copies of the draft document "US Public Health Service Recommendations for HIV Counseling and Testing for Pregnant Women" may be obtained from the CDC's National AIDS Clearinghouse, PO. Box 6003, Rockville, MD 208496003, telephone (800) 4585231.

FROM: CDC Press Release: CDC's draft guidelines for HIV counseling and voluntary testing for pregnant women; February 1995.

Additional news items in this issue: Community Exposure Predicts Healthcare Worker TB Skin-Test Conversion (page 330), Serosurvey Finds Surgeons at Greatest Risk for Hepatitis B (page 334), Community Outbreak of Legionnaires' Disease from Hospital Cooling Tower (page 339), Newly Identified Virus Kills Trainer and 14 Horses in Australia (page 347), New Hepatitis Viruses Identified (page 353), Diphtheria Epidemic in the Newly Independent States of the Former Soviet Union (page 358), Clarification of Hepatitis B Vaccine Dose for Infants (page 364). 


\section{Frontune HealthCare Workers: National Conference on Prevention of SHARPS INI URIES AND BLOODBORNE EXPOSURES August 14-16, 1995 \\ Hyatt Regency Atlanta}

\section{Speakers}

David M. Bell-Occupational Risk of Bloodbome Pathogens Transmission

Linda Chiarello, RN;: MPH-Selection of Needlestick Prevention Devices

Janine J agger, PhD-Sharps finjuries and Bloodbome Exposure Survellance

James S. Benson-Obstacles and Opportunities for Medical Device Manufacturers

Dr. Annie LePrince-Needlestick Injury Surveillance and Engineering Controls in Europe

Patti Wetzel, MD-Risk Assessment-A Realistic Focus

Munay L Cohen, PhD, ClH-will chair the conference and present historical prospectives and future trends.
For more information or a registration form contact ACGIH 1330 Kemper Meadow Drive Cinc innati, Ohio 45240- 1634 (513) 742-2020 . Fax (513) 742-3355 IntemetACGIH_mem@pol.com

\section{Exhibitors}

Advancesin Exposure Prevention

Becton Dic kinson and Company

Deltec

STERIS Corporation

Terumo Medical Corporation

MANZI MARKEIING COMPANY

Sterile Dental Systems, Inc.

JOHNSON \&JOHNSON MEDICAL, INC.

Infection Control \& Sterilization Technology

B. Braun Medical Inc.

BIOJECT INC.

ZEROWET SPLASHIELD

Sherwood Medical

Owen Mumford, Inc.

Sage Products Inc.

McGaw, Inc.

3M Health Care

Uvex Safety, Inc

SAFETY SYRINGES, INC.

Associated Enterprises, Inc.

RACAL HEALTH AND SAFETY, INC.

St. Paul Medical, Inc.

Gainor Medical

Costal Video

RESEARCH MEDICAL SYSTEMS LTD

InjectiMed,Inc.

Q CARE INTERNATIONAL

Bard Urological

Kimberly-Clark Corporation

MedScience

Stermatic

U.S. Medic al Instruments, Inc. 


\section{THE SOCIETY FOR HEALTHCARE EPIDEMIOLOGY OF AMERICA Membership Application}

Name: Degree M.D.

Ph.D.

Other:

Hospital Position (if applicable):

Area of interest within hospital epidemiology: (Check all that apply) Antimicrobial use

-Cost-benefit research

-Health services research

-Intravascular device-associated infection

Other (specify)

Business Address:
Nosocomial pneumonia

Nosocomial urinary tract infection

Outcome indicators

Pharmacoepidemiology
Protective devices and equipment QA, CQI, QM, etc.

-Surgical site infection

Home Address:

Home telephone: (2-

City $\quad$ State $\quad$ Zip Code

Indicate preferred address for correspondence, journal, and membership directory listing

Home Business

How/Where did you hear about SHEA?

MEMBERSHIP FEE: (Non-U.S. members pay with draft for U.S. dollars)

Active Membership (Calendar year dues \$85)*

Applicants must hold a doctoral degree and should either work in the field of healthcare epidemiology or have a direct interest in healthcare epidemiology.

Associate Membership (Calendar year dues \$35)*. Training Program ends in _ / _

Mo. Yr.

Applicants must hold a doctoral degree and be participating in an appropriate training program. Proof of training must accompany this application.

Membership Fee includes subscription to the Society's official journal, Infection Control and Hospital Epidemiology

* Additional postage fee will appear on dues statements for foreign mailing of journal.

Send Application and Remittance To: SHEA Membership Department

875 Rings Highway, Suite 200

Woodbury, NJ 08096-3172

609-845-1636

609-853-0411 FAX 